\section{Humane Herpes-8-Viren}

W. Stöcker

Euroimmun Medizinische Labordiagnostika AG, Lübeck, Deutschland

Synonym(e) Human herpes virus type 8

Beschreibung des Erregers Das humane Herpes-Virus 8, erstmals im Jahr 1994 beschrieben, wird aufgrund seiner Entdeckung im Gewebe von Kaposi-Sarkomen auch als Kaposi-Sarkom-Herpes-Virus (KSHV) bezeichnet. HHV-8 infiziert in erster Linie B-Lymphozyten, die auch den Ort der Latenz darstellen.

HHV-8 gehört zur Familie Herpesviridae (behüllte Viren mit einer doppelsträngigen, linearen DNA als Genom), Unterfamilie $\gamma$-Herpesvirinae, Gattung Rhadino-Virus. Die Virionen (Durchmesser $140 \mathrm{~nm}$ ) bestehen aus einem ikosaedrischen Kapsid, das von Tegumentproteinen umkleidet und von einer äußeren Virushülle umgeben ist. Reservoir für HHV-8 ist ausschließlich der infizierte Mensch, der das Virus auch asymptomatisch ausscheiden kann.

Erkrankungen Die Primärinfektion des Mund- und Rachenraums mit HHV-8 verläuft bei Immungesunden in den meisten Fällen asymptomatisch, gelegentlich treten Fieber oder ein Exanthem auf. HHV-8 ist ätiologisch an der Entstehung des Kaposi-Sarkoms beteiligt, an dem bevorzugt AIDSPatienten erkranken. Zudem scheinen verschiedene seltene lymphoproliferative Erkrankungen, z. B. das primäre Ergusslymphom (PEL) und eine Variante der multizentrischen Castleman-Erkrankung (MCD), mit dem Virus assoziiert zu sein. Das Virus wird insbesondere durch Speichel und auf sexuellem Weg übertragen. Die Durchseuchung in Deutschland ist im Vergleich zu anderen Herpes-Viren mit 1-8\% niedrig, in Afrika liegt die Seroprävalenz bei $50 \%$.
Analytik Direkter Erregernachweis mittels $>$ PCR (Polymerase-Kettenreaktion). Der immunhistochemische Nachweis von HHV8-LNA (,latent nuclear antigen“) in formalinfixiertem, paraffineingebettetem Material ist ebenfalls möglich. Antikörperdiagnostik mittels indirekter Immunfluoreszenz ( $\triangleright$ Immunfluoreszenz, indirekte) oder $\triangleright$ Enzyme-linked Immunosorbentassay.

Untersuchungsmaterial - Probenstabilität Direktnachweis und Kultur: Untersucht werden Speichel, Blut sowie Biopsien aus Kaposi-Sarkomen. Das Material sollte bis zur Weiterverarbeitung bei +4 bis $+8{ }^{\circ} \mathrm{C}$ aufbewahrt werden. Direktnachweise sind innerhalb von 24 Stunden durchzuführen, Kulturen innerhalb von 6 Stunden anzulegen. Bei längerer Transportzeit ist das Material einzufrieren.

Serologie: Serum oder Liquor für den Nachweis der Antikörper sind bei $+4{ }^{\circ} \mathrm{C}$ bis zu 2 Wochen lang beständig, bei $-20^{\circ} \mathrm{C}$ über Monate und Jahre hinweg. Zur Tiefkühlkonservierung des IgM kann man den Proben 80 \% gepuffertes Glyzerin beifügen.

Diagnostische Wertigkeit Wenn es gilt, eine Infektion mit HHV-8 festzustellen, zeigen Speichelproben für den direkten Erregernachweis die höchste Sensitivität. Für die Diagnostik HHV-8-assoziierter Erkrankungen muss Biopsiematerial eingesetzt werden, eine negative PCR aus suspektem Tumorgewebe spricht gegen ein Kaposi-Sarkom. Ein positiver Anti-HHV-8IgG-Befund kann den Verdacht einer HHV-8-Infektion oder einer damit assoziierten Krankheit bestätigen, ein negativer Befund schließt eine Infektion nicht aus.

\section{Literatur}

Chang Y, Cesarman E, Pessin MS, Lee F, Culpepper J, Knowles DM, Moore PS (1994) Identification of herpesvirus-like DNA sequences in AIDS-associated Kaposi's sarcoma. Science 266:1865-1869

Edelman DC (2005) Human herpesvirus 8 - a novel human pathogen. Virol J 2:78. Review 